\title{
Toxicity of Fenthion to Anastrepha fraterculus (Wied.) (Diptera:Tephritidae): Dose Response Analysis
}

\author{
Ivana B. M. Da Cruz ${ }^{1}$, Eduardo Humeres² ${ }^{2}$ and Alice K. Oliveira ${ }^{3}$ \\ ${ }^{1}$ Laboratório de Genética e Biologia do Desenvolvimento, Instituto de Biociências-PUCRS, \\ Caixa postal 1429, 90619-000, Porto Alegre, RS. \\ ${ }^{2}$ Estação Experimental de São Joaquim, Empresa de Pesquisa Agropecuária e Extensão \\ Rural de Santa Catarina S.A. (EPAGRI), Caixa postal 81, \\ 88.600-000, São Joaquim, SC. \\ ${ }^{3}$ Departamento de Genética, Instituto de Biociências, UFRGS, Caixa postal \\ 15053, 91 501-970, Porto Alegre, RS.
}

An. Soc. Entomol. Brasil 26(3): 471-479 (1997)

Toxicidade de Fention em Anastrepha fraterculus (Wied. ) (Diptera: Tephritidae): Análise da Resposta à Dose

RESUMO - Três bioensaios toxicológicos foram feitos na $F_{1}$ de duas populações sul brasileiras de Anastrepha fraterculus (Wied.). A dose letal de fention para matar $50 \%$ e $90 \%$ da população foi estimada somente em dois bioensaios: por contato residual e administração oral. Resultados da aplicação tópica, usando fention diluido em álcool, acetona ou água, não foram consistentes. Isto, porque foi observada uma alta mortalidade nas amostras controle, tratadas somente com álcool ou acetona (>10\%), enquanto que nas amostras tratadas com água não foi observada uma resposta linear entre a dose e a mortalidade. $\mathrm{O}$ bioensaio por contato residual foi significativamente mais tóxico quando comparado com o de administração oral, sendo que os coeficientes angulares obtidos nos dois testes foram os mesmos para machos e fêmeas das populações estudadas. Um teste adicional para avaliar repelência ao inseticida mostrou não haver discriminação dos insetos por dietas com ou sem fention.

PALAVRAS-CHAVE: Insecta, mosca-das-frutas, inseticida, toxicidade.

ABSTRACT - Three toxicological bioassays were performed in two F1 south Brazilian field populations of Anastrepha fraterculus (Wied.). Lethal doses of fenthion $(50 \%$ and $90 \%)$ were estimated in two bioassays, with oral administration, and with residual contact bioassay. Results of topical bioassays using fenthion diluted in alcohol, acetone or water were inconsistent. Samples treated with acetone or alcohol diluents presented high mortality $(>10 \%)$, while the samples treated with water diluent showed a non linear response between dose and mortality. The residual contact bioassay was significatively more toxic when compared to a feeding bioassay, occurring equal slopes in males and females in the populations analysed. Additional test showed that insects did not discriminate between diets with and without fenthion.

KEY WORDS: Insecta, South American fruit fly, insecticide, toxicity. 
The South American fruit fly, Anastrepha fraterculus (Wied.) is highly polyphagous and known to attack several cultivated and wild fruits (Malavasi et al. 1980, Norrbom \& Kim 1988). In southern Brazil this species causes severe internal and external damage to apple (Malus domestica L.) orchards (Salles 1995a, b). In the green fruit stage, fly oviposition causes deformation and fruit fall. In later fruit stages the internal damage caused by the larvae is most severe (Orth et al. 1986).

In spite of very little $A$. fraterculus adult eclosion from apple, fruit fly population density in the São Joaquim, SC, infested region is high because there is a wide range of wild and facultative host plants near the orchards (Hickel \& Ducroquet 1993, 1994). Studies carried out so far show that apple is considered a satisfactory host (R. Sugayama, pers. commun.).

The standard procedure to control $A$. fraterculus are poisoned bait sprays around the orchard and organophosphate insecticide sprays (Orth et al. 1986, Barros et al. 1991). Among several insecticides, fenthion, is used since the 1960's but studies have been limited to field experiments (Roessler 1989, Salles 1995a), and basic toxicity data for $A$. fraterculus have not been reported.

Laboratory bioassays can determine the relative toxicity of pesticides among pest populations by comparing each population response to a series of pesticide concentrations or to a single diagnostic concentration (Roush \& Tabashnik 1990). The establishment of an economic, accurate and fast toxicitystandard method is crucial for fruit fly integrated pest management (IPM).

In this paper, the basic toxicity and general handling methods for residual contact, topical, and feeding application, and repellence test for two A. fraterculus populations were analysed to provide baseline data for fenthion use in the management of this fruit fly species.

\section{Material and Methods}

Insects. Two A. fraterculus populations were collected in the town of São Joaquim-SC from fruits of feijoa (Feijoa sellowiana). The first population named Saul (S) was collected from wild host plants and the second one named Osni (O) was collected from a house back yard cultivated plant with previous history of insecticide contact. The fruits were kept in plastic containers with sterilized garden soil and after 15 days the pupae were collected and transferred to separate screen wooden cages $(25 \times 25 \times 25 \mathrm{~cm})$ where the adult flies emerged and were provided with food (a past with $3: 1$ $\mathrm{wt} / \mathrm{wt}$ of brown sugar, soybean hydrolisate protein dissolved in distilled water) through cotton wicks. Food and water sources were placed on the top of each cage and covered with plastic cling wraps taped to the cage to prevent desiccation. The populations were reared separate to evaluate their responses to organophosphate toxicity. The insect rearing laboratory conditions consisted of $25^{\circ} \mathrm{C} \pm$ $2^{\circ} \mathrm{C}, 80 \% \mathrm{RH}$ and 14:10 (L:D). Papaya fruit was used as larval substrate (Da Cruz et al. 1994) to obtain the generation $\left(F_{1}\right)$ which was used in the laboratory bioassays.

Bioassay Procedures. Different concentrations of fenthion [0,0-dimethyl-0,3(methylmercapte-4-methylphthiophenyl) thiophosphate 0,0 - Dimethyl-0-(3-methyl-4methylthio- phenyl) phosphorothionate] 500 $\mathrm{CE}$ were used. The flies used were 30 days old because this age corresponds to their reproductive peak and also to greater fruit damage (Orth et al. 1986). Fenthion doses (ppm) that caused 10 to $95 \%$ mortality were used (Robertson \& Preissler 1992). Flies that did not move any appendage when picked up with tweezers, were counted as dead. Each treatment was replicated five times, including controls. Residual contact, feeding and topical bioassays, plus a complementary repellence test were carried out.

In residual contact bioassay, fenthion was prepared using alcohol as diluent. Each dilution $(6 \mathrm{ml})$ was placed inside glass containers $(180 \mathrm{ml})$ and stirred for 60 seconds. The glass was then dried under laboratory conditions. Flies were grasped by the wings with tweez- 
ers and then placed inside the fenthion-treated glass containers. Preliminary concentrations tests $[0.0,0.23,0.37,0.58,0.90,0.95,1.00$, $1.46,2.15,3.16,4.64,6.80$ and 10 ppm (AI) ] logarithmicaly determinated were performed with males and females of each population treated to bracket effective concentrations. In this bioassay, 10 males and 10 females, and seven concentrations were used in each replication. After 24 hours the mortality was observed.

Topical bioassay was carried out as described for the Caribbean fruit fly Anastrepha suspensa (Nigg et al. 1994). Flies were anesthetized with ether for $1 \mathrm{~min}$, and placed in an open Petri dish. Exposure up to $10 \mathrm{~min}$ to ether did not show effects over $A$. fraterculus biological properties as pre-imaginal development and adult viability (C. G. Bicca, pers. commun.). The flies were treated by grasping a wing with tweezers and applying $1 \mathrm{ml}$ of test solution to the thorax. Alcohol, acetone and water were used as diluents. Similar serial fenthion dilutions described for residual contact bioassay were used for topical application. After treatment, the insects were placed in a single glass container and the mortality evaluated after 24 hours exposure. In each topical diluent test 10 males and 10 females were used for each replication.

In feeding bioassay the fruit fly diet was made up using $15 \mathrm{~g}$ hydrolysate protein, $30 \mathrm{~g}$ brown sugar and $10 \mathrm{ml}$ tap water which was stirred for $10 \mathrm{~min}$. Different concentrations of the insecticide fenthion diluted in water was mixed with diet and $0.5 \mathrm{~g}$ of the resulting paste was placed on the top of $30 \mathrm{ml}$ glass bottle on a gauze tissue. Ten flies of each sex and from each population, were placed in individual containers. To be sure that $A$. fraterculus effectively fed on this paste containing insecticide $2 \mathrm{~g}$ Ponceau dye (Sigma) were added to the diet. The red color of the abdomen was indicative of diet consumption. After $24 \mathrm{~h}$ and $48 \mathrm{~h}$ of exposure the mortality was evaluated. The same preliminary tests concentrations made in residual contact bioassay $[0.0,0.23$, $0.37,0.58,0.90,0.95,1.0,1.46,2.15,3.16$, $4.64,6.80,10.0$, adding 20, 40, 60 and 80 ppm (AI)] were performed with 150 males and 150 females of the two populations treated to bracket effective concentrations. In this bioassay, 10 males and 10 females, and seven concentrations were used in each replication.

The repellent effect of fenthion was also studied. The flies were left without food and water during 12 hours, and then transferred to a $250 \mathrm{ml}$ glass containing diet with and without fenthion (10 ppm commercial concentration). Five evaluations with two-hour intervals were made by counting the number of feeding flies. In this experiment, 20 males and 20 females were used in each replication.

Statistical analysis consisted of regression estimated by Probit analysis; hypothesis of equality of regressions was tested by likelihood ratio test [POLO-PC, (Le Ora Software 1987, Berkerley, CA)]. The repellence experiment data were analysed following completely randomized one-way analysis of variance (ANOVA).

\section{Results}

In the residual contact bioassay the toxicity was high and no significant differences were found between populations and between males and females (Table 1, Fig. 1), because the slopes and intercepts were the same $[\chi 2$ $=2.86$, degrees of freedon $(\mathrm{df})=6]$ and lines were parallel $[\log (\mathrm{L})=-149.1]$. The heterogeneity of samples tested was also low $(0.64$, $\mathrm{g}=0.134)$.

Results of topical bioassay were inconsistent because tests using only the diluents alcohol and acetone showed mortality higher than $10 \%$ and the data obtained using water as diluent did not show a linear response (Fig. 2). Therefore, this type of bioassay is not adequate to measure the $A$. fraterculus insecticide toxicity and to evaluate $\mathrm{LD}_{50}$ and $\mathrm{LD}_{90}$.

In the feeding bioassay, as observed in the residual contact test, no significant differences were found between sexes and populations studied (Table 2, Fig. 3). The slope and intercepts were the same $(\chi 2=1.607, \mathrm{df}=6)$ and the lines were parallel $[\log (\mathrm{L})=129.8]$, with low heterogeneity of tested samples $(0.66, \mathrm{~g}$ 
Table 1. Concentration-response after 24 hs exposure of males and females of Anastrepha fraterculus to residual contact bioassay.

\begin{tabular}{lllll}
\hline Pop $^{3}$ & $\mathrm{n}$ & Slope $\mathrm{SEM}^{1}$ & $\mathrm{LD}_{50}(95 \% \mathrm{FL}) \mathrm{ppm}^{2}$ & $\mathrm{LD}_{90}(95 \% \mathrm{FL}) \mathrm{ppm}$ \\
\hline $\mathrm{OM}$ & 350 & $5.94 \pm 2.17$ & $1.049(0.932-1.182)$ & $1.770(1.507-2.323)$ \\
$\mathrm{OF}$ & 350 & $5.94 \pm 2.11$ & $1.112(0.991-1.262)$ & $1.876(1.584-2.508)$ \\
$\mathrm{SM}$ & 350 & $6.72 \pm 2.19$ & $1.089(0.970-1.234)$ & $1.838(1.555-2.444)$ \\
SF & 350 & $4.15 \pm 2.01$ & $1.200(1.071-1.380)$ & $2.025(1.688-2.780)$ \\
\hline
\end{tabular}

${ }^{1}$ Results of analysis for adult $(\chi 2=0.83, \mathrm{df}=3 \mathrm{P}>0.842$, heterogeneity $=0.64 ; \mathrm{g}=0.134)$. ${ }^{2}$ The hypothesis of equality between $\mathrm{LD}_{50}$ cannot be rejected in the samples tested. ${ }^{3} \mathrm{OM}=$ Osni male; $\mathrm{OF}=$ Osni female; $\mathrm{SM}=$ Saul male; $\mathrm{SF}=$ Saul female.

$=0.73$ ).

However, the insecticide concentration to obtain the $\mathrm{LD}_{50}$ in feeding bioassay was very high compared to the $\mathrm{LD}_{50}$ of residual con- tact bioassay. Whereas in the feeding experiment the mean concentration was $20.51 \pm 0.74$ ppm, in the residual contact this mean value was $1.11 \pm 0.14 \mathrm{ppm}$. The mortality was simi-
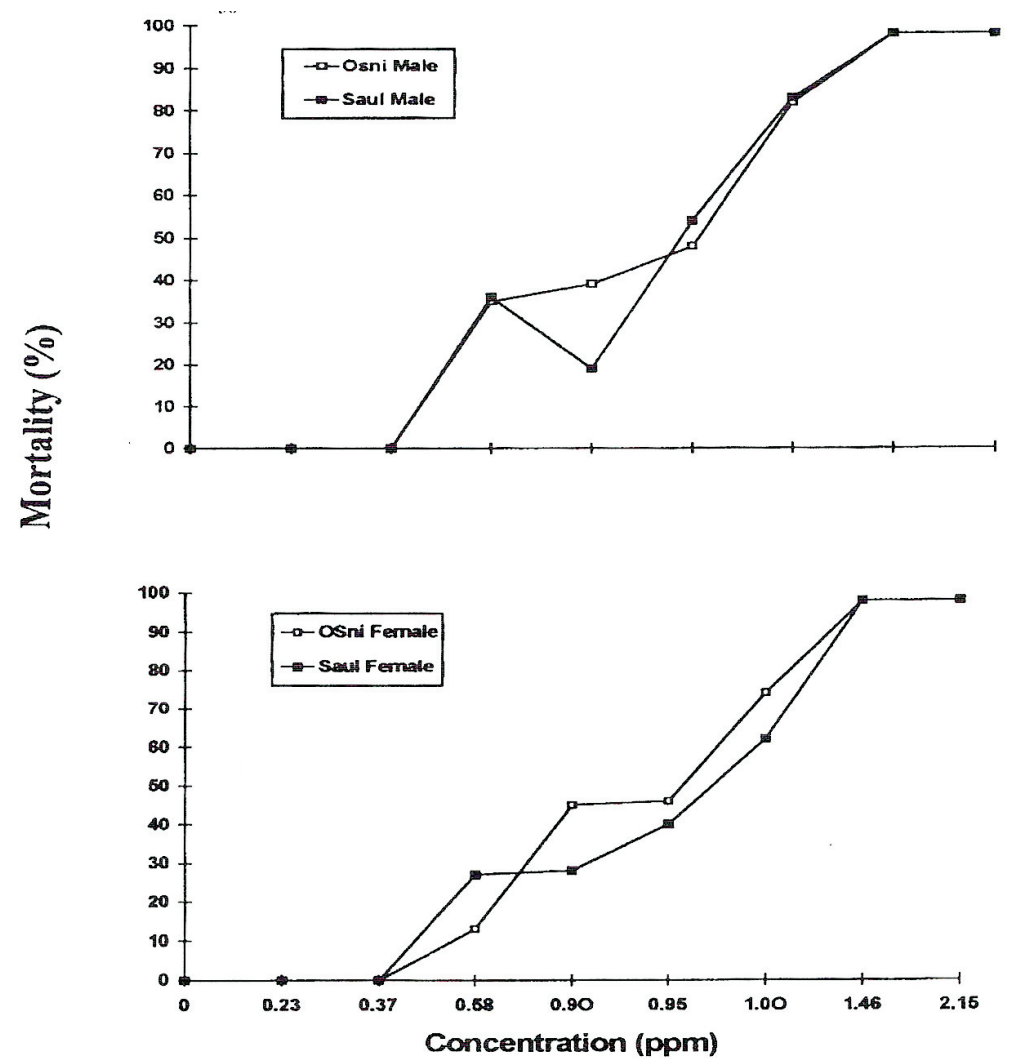

Figure 1. Comparison of male and female Anastrepha fraterculus mortality responses to residual contact bioassay of fenthion in the two populations tested. 
A

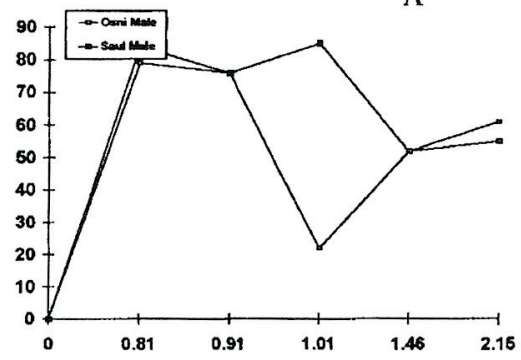

B
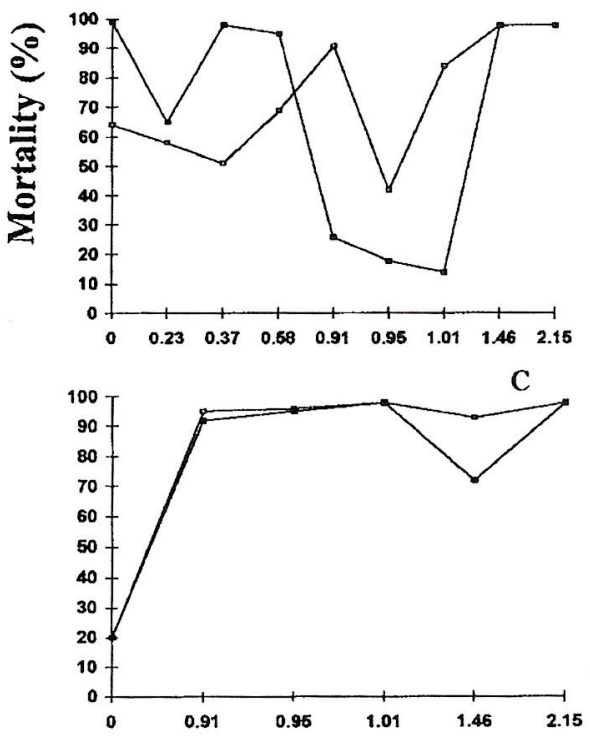

A

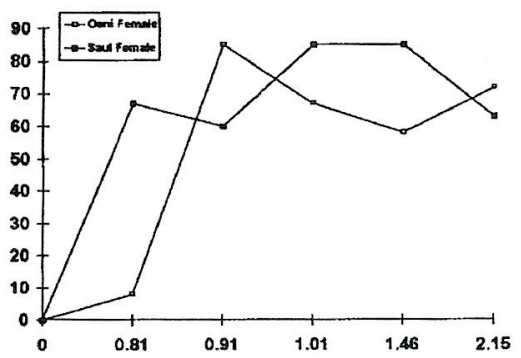

B
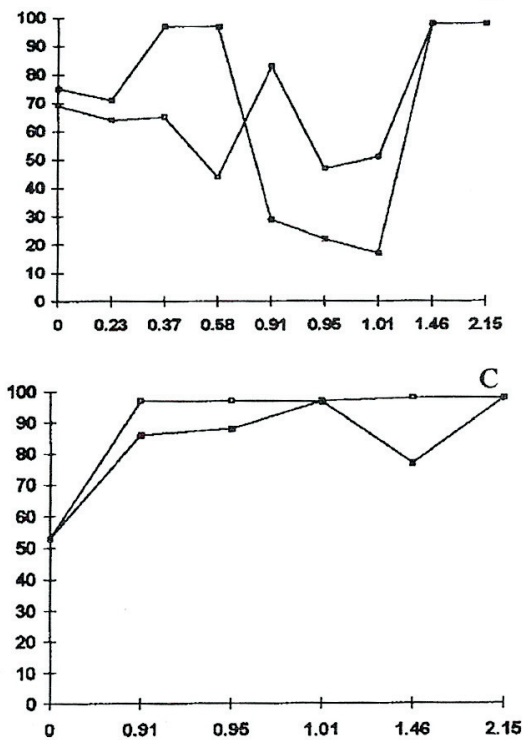

\section{Concentration (ppm)}

Figure 2. Comparison of male and female Anastrepha fraterculus mortality responses to topical bioassay of fenthion using three solvents: $\mathrm{A}=$ alcohol; $\mathrm{B}=$ acetone; $\mathrm{C}=$ water in the two populations tested.

lar in samples treated with concentrations lower 10ppm after $24 \mathrm{~h}$ and $48 \mathrm{~h}$ exposure.

In the repellence test, males and females showed similar behavior. Diets with or without fenthion were not discriminated by the flies. In each time interval the mean feeding frequencies of males and females treated without fenthion were $41 \%$ and $39 \%$ respectively whereas in those treated with fenthion the frequencies were $38 \%$ and $43 \%$.

\section{Discussion}

The proposition of standard toxicity method is crucial to understand the insecticide effect over the mortality of $A$. fraterculus, to evalute future risks of pest resistance appearance (Robertson \& Preisler 1992) and to understand its ecological relationship with other species, such as parasitoids used in biological control programs (Purcell et al. 1994). 
Table 2. Concentration-response after 24 hs exposure of males and females of Anastrepha fraterculus to fenthion feeding bioassay.

\begin{tabular}{llllr}
\hline Pop $^{3}$ & $\mathrm{n}$ & Slope $\mathrm{SEM}^{1}$ & $\mathrm{LD}_{50}(95 \% \mathrm{FL}) \mathrm{ppm}^{2}$ & $\mathrm{LD}_{90}(95 \% \mathrm{FL}) \mathrm{ppm}$ \\
\hline $\mathrm{OM}$ & 350 & $1.22 \pm 0.78$ & $19.983(4.817-37.230)$ & $90.593(48.221-434.658)$ \\
OF & 350 & $2.32 \pm 0.79$ & $23.790(6.959-43.893)$ & $107.852(56.704-629.594)$ \\
$\mathrm{SM}$ & 350 & $1.90 \pm 0.78$ & $22.389(6.196-41.344)$ & $101.501(53.646-558.136)$ \\
SF & 350 & $2.42 \pm 0.86$ & $15.889(2.968-31.127)$ & $72.032(37.174-290.522)$ \\
\hline
\end{tabular}

${ }^{1}$ Results of analysis for adult $(\chi 2=1.38, \mathrm{df}=3 \mathrm{P}>0.708$, heterogeneity $=0.66 ; \mathrm{g}=0.135)$. ${ }^{2}$ The hypothesis of equality between $\mathrm{LD}_{50}$ cannot be rejected in the samples tested. ${ }^{3} \mathrm{OM}=$ Osni male; $\mathrm{OF}=$ Osni female; $\mathrm{SM}=$ Saul male; $\mathrm{SF}=$ Saul female.

Results showed that residual contact and feeding bioassays can be used to evaluate fenthion toxicity in A. fraterculus indicating the more effective and supplying a general handline to study other insecticides in this species.

The $\mathrm{LD}_{50}$ value for feeding bioassay was 18.48 times higher than the one obtained for residual contact bioassay. These differences

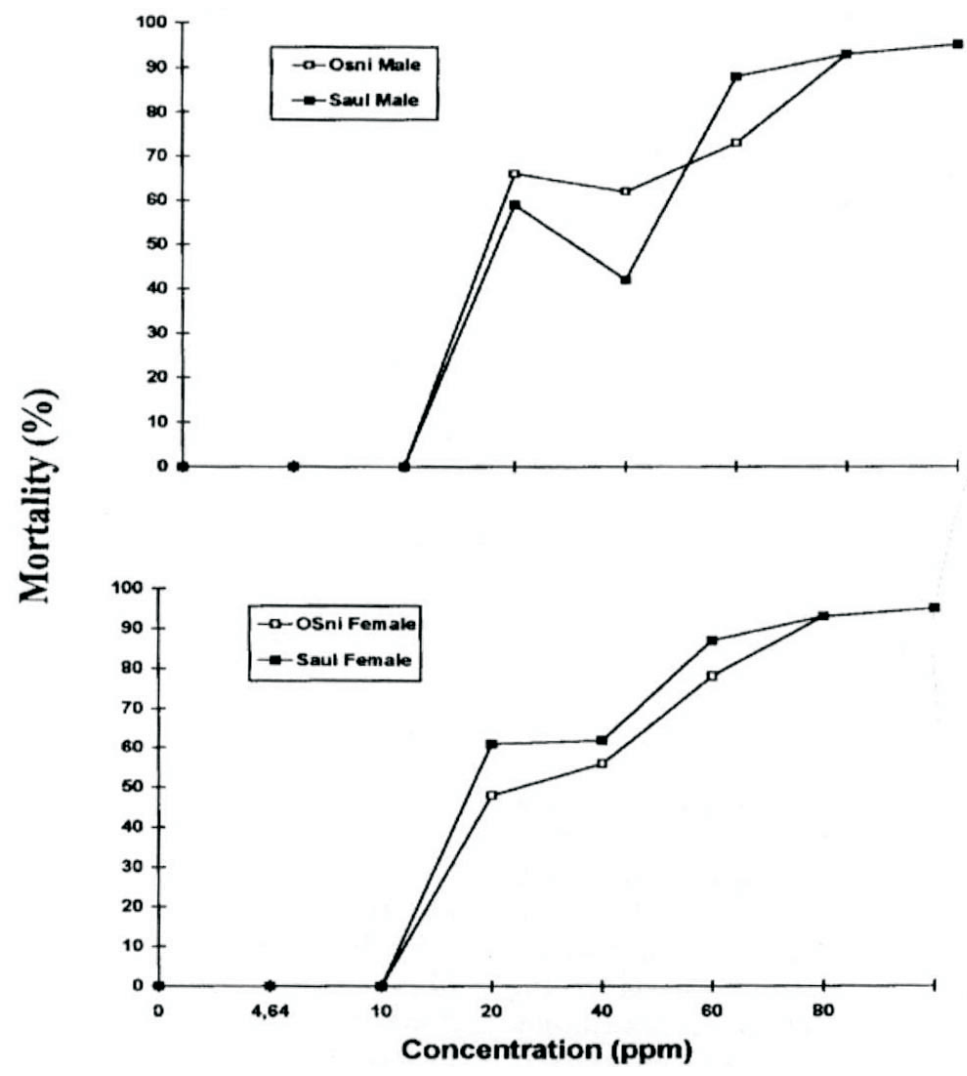

Figure 3. Comparison of male and female Anastrepha fraterculus mortality responses to feeding bioassay of fenthion in the two populations after $24 \mathrm{~h}$ exposure. 
can be explained by two hypothesis not mutually excludent: If it is assumed no pesticide degradation, the high toxicity observed in the contact residue test could be due to the continuous exposure of flies to fenthion. In contrast, in the feeding experiment fenthion was mixed with food and placed on the top of the glass container over a gauze tissue which made difficult the direct contact of the fly with the insecticide, and the feeding was variable and discontinuous. This discontinuous exposure to fenthion in feeding bioassay could allow the activation of fly general detoxification mechanisms; and high insecticide degradation when mixed with food. This hypothesis was suggested by Costilla \& Basco (1978) and Salles (1995a), who found that insecticides mixed with atractants cause high mortality only until six hours of fly exposure. After this time the toxicity effect decreased dramatically.

Once the repellence test showed that the flies fed similarly on diets with and without fenthion, additional studies are required in order to analyse these two hypothesis (discontinuity effect and insecticide degradation), because toxic baits are currently used in fruit fly management and aerial spray programs may have undesirable ecological effects (Ehler \& Endicott 1984).

In the feeding bioassay body weight was not considered. This because in body weight one can not determined how much insecticide was ingested by each fly (Nigg et al. 1994). Robertson \& Preisler (1992) previously described problems involved in the use of weight as a variable in toxicity testing. However, as M. Taufer (pers. commun.) showed, 30 days old females are heavier than males with the same age and as the response in feeding bioassay was similar in males and females this suggests that this variable is not important in fruit fly toxic response.

Like A. suspensa (Nigg et al. 1994), the South American fruit fly is also difficult to manipulate in toxicity tests. The negative ether action was discharged because preliminary experiments did not show any effect until 10 minutes after ether exposure, over several fruit fly biological properties as pre-imaginal development, viability, fertility and fecundity (C. G. Bica, pers. commun.). However our topical bioassay had unexpected results related with the treatments used. The mortality in this bioassay was variable including control samples where acetone, alcohol and water diluents were used without insecticide. Acetone, which is normally used as a diluent, proved to be inefficient in topical bioassay and this may be due to species low tolerance. The response to alcohol may be a consequence of a low amount of alcohol dehydrogenase (ADH) enzyme in the adult fly (J. C. Nascimento, pers. commun.) Since alcoholic attractive baits are currently used for A. fraterculus (Salles 1995b) in the future it will be important to investigate the levels of alcohol tolerance under several biological conditions as adult age, reprodutive behavior, etc. The results found using water as diluent may be accounted by its low evaporation which can be responsible for wing damage followed by death. As this is a stochastic phenomenon, the results obtained did not present a regular pattern and thus were inconclusive. All these considerations indicate that topical bioassay is not a good test to measure toxicity effects over A. fraterculus.

The similar biological response to fenthion in males and females of the two populations studied in laboratory conditions suggests a similar genetic composition. However the $\mathrm{LD}_{50}$ differences observed in feeding and residual contact bioassay suggest that the time of exposure can be a critical variable in the fruit fly insecticide effect. Since $A$. fraterculus is an opportunistic and highly mobile insect (Aluja 1994), the standartization of laboratory toxicity bioassays is important to predict what could happen in the field and to help in the implementation of an effective and realistic integrated fruit fly management.

\section{Acknowledgements}

We are grateful to Associação Brasileira de Produtores de Maçã (ABPM), Conselho Nacional de Desenvolvimento Científico e 
Tecnológico (CNPq) and Financiadora de Estudos e Projetos (FINEP) for grants and fellowships.

\section{References Cited}

Aluja, M. 1994. Bionomics and management of Anastrepha. Annu. Rev. Entomol. 39:155-178.

Barros, M.D., P.M. Amaral \& A. Malavasi. 1991. Comparison of glass and plastic McPhail traps in the capture of the South American fruit fly Anastrepha fraterculus (Diptera: Tephritidae) in Brazil. Fla. Entomol. 74: 467-468.

Costilla, M.A. \& H.J. Basco. 1978. Comportamiento de ebos para el control de las moscas de la fruta en quintas citricas. Rev. Ind. Agric. Tucuman 54: 4145.

Da Cruz, I.B.M., V.L.G. Valente \& A.K. Oliveira. 1994. Occurrence of polytene chromosomes in Anastrepha fraterculus (Diptera: Tephritidae). Cytobios 79:4550.

Ehler, L.E. \& P.C. Endicott. 1984. Effect of malathion-bait sprays on biological control of insect pests of olive, citrus and walnut. Hilgardia 52: 1-47.

Hickel, E.R. \& J.P.H.J. Ducroquet. 1993. Flutuação populacional de espécies de Anastrepha (Diptera: Tephritidae) relacionada com a fenologia de frutificação do pêssego e ameixa em Santa Catarina. An. Soc. Entomol. Brasil 22: 591-596.

Hickel, E.R. \& J.P.H.J. Ducroquet. 1994. Ocorrência de mosca-das-frutas Anastrepha fraterculus (Wied.) em frutas de goiabeira serrana. An. Soc. Entomol. Brasil 23: 311-315.

Le Ora Software. 1987. POLO-PC: a user's guide to probit or logit analysis. Le Ora Software, Berkeley, CA.

Malavasi, A., J.S. Morgante \& R.A. Zucchi. 1980. Biologia de "mosca-das-frutas"(Diptera:Tephritidae). I. Lista de hospedeiros e ocorrência. Rev. Brasil. Biol. 40: 9-16.

Nigg, H.N., L.L. Mallory, S. Fraser, S.E. Simpson, J.L. Robertson, J.A. Attaway, S.B. Callaham \& R.E. Brown. 1994. Test protocols and toxicity of organophosphate insecticides to Caribbean fruit fly (Diptera: Tephritidae). J. Econ. Entomol. 87: 589-595.

Norrbom, A.L. \& K.C. Kim. 1988. A list of reported host plant of the species of Anastrepha (Diptera: Tephritidae). USDA-APHIS. Misc. Publ. 52-81.

Orth, A.I., L.G Ribeiro, \& W. Reis Filho. 1986. Manejo de pragas. p. 341-379. In Manual da cultura da macieira, Empresa Catarinense de Pesquisa Agropecuária S.A., Florianópolis.

Purcell, M.F., J.D. Stark \& H.M. Russel. 1994. Insecticide effect on three tephritid fruit flies and associated braconid parasitoids in Hawaii. J. Econ. Entomol. 87: 1455-1462.

Robertson, J.L. \& H.K. Preisler. 1992. Pesticide bioassays with arthropods. Boca Raton, CRC Press, 157p.

Roessler, Y. 1989. Insecticidal bait and cover sprays, pp. 329-336. In A.S. Robinson \& Hopper [eds], Fruit flies: their biology, natural enemies and control. Elsevier, Amsterdam, 447p.

Roush, R. T. \& B. E. Tabashnik. 1990. Pesticide resistence in Arthropods. New York, London, Chapman and Hall, 303p.

Salles, L.A.B. 1995a. Isca tóxica para o 
controle de adultos de Anastrepha fraterculus (Wied.) (Diptera: Tephritidae). An. Soc. Entomol Brasil. 24: 153157. da mosca-das-frutas sul-americana. Bol. $\mathrm{N}^{\mathrm{o}}$ 1, EMBRAPA, CPATC, Pelotas. 25p.

Salles, L.A.B. 1995b. Bioecologia e controle Received 12/VIII/96. Accepted 24/IX/97. 